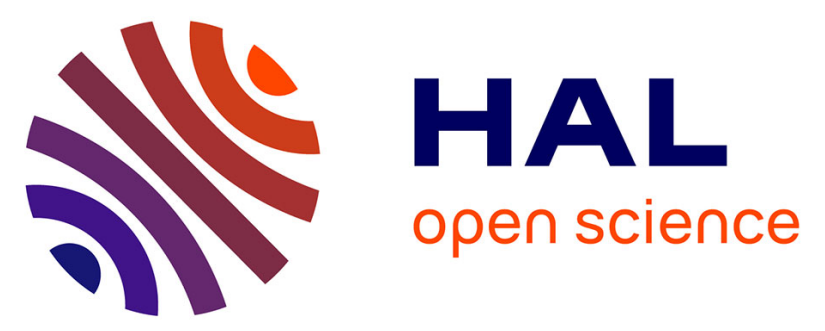

\title{
Diagnosing occult tumour cells and their predictive value in sentinel nodes of histologically negative patients with colorectal cancer
}

\author{
E.S. van Der Zaag, N. Kooij, M.J. van de Vijver, W.A. Bemelman, H.M. \\ Peters, C.J. Buskens
}

\section{To cite this version:}

E.S. van Der Zaag, N. Kooij, M.J. van de Vijver, W.A. Bemelman, H.M. Peters, et al.. Diagnosing occult tumour cells and their predictive value in sentinel nodes of histologically negative patients with colorectal cancer. EJSO - European Journal of Surgical Oncology, 2010, 36 (4), pp.350. 10.1016/j.ejso.2009.11.008 . hal-00576162

\section{HAL Id: hal-00576162 \\ https://hal.science/hal-00576162}

Submitted on 13 Mar 2011

HAL is a multi-disciplinary open access archive for the deposit and dissemination of scientific research documents, whether they are published or not. The documents may come from teaching and research institutions in France or abroad, or from public or private research centers.
L'archive ouverte pluridisciplinaire HAL, est destinée au dépôt et à la diffusion de documents scientifiques de niveau recherche, publiés ou non, émanant des établissements d'enseignement et de recherche français ou étrangers, des laboratoires publics ou privés. 


\section{Accepted Manuscript}

Title: Diagnosing occult tumour cells and their predictive value in sentinel nodes of histologically negative patients with colorectal cancer

Authors: E.S. van der Zaag, N. Kooij, M.J. van de Vijver, W.A. Bemelman, H.M. Peters, C.J. Buskens

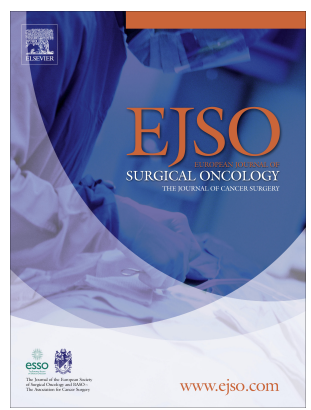

PII:

S0748-7983(09)00516-2

DOI: 10.1016/j.ejso.2009.11.008

Reference: $\quad$ YEJSO 2919

To appear in: European Journal of Surgical Oncology

Received Date: 12 July 2009

Revised Date: 11November2009

Accepted Date: 16 November 2009

Please cite this article as: van der Zaag ES, Kooij N, van de Vijver MJ, Bemelman WA, Peters HM, Buskens CJ. Diagnosing occult tumour cells and their predictive value in sentinel nodes of histologically negative patients with colorectal cancer, European Journal of Surgical Oncology (2009), doi: 10.1016/ j.ejso.2009.11.008

This is a PDF file of an unedited manuscript that has been accepted for publication. As a service to our customers we are providing this early version of the manuscript. The manuscript will undergo copyediting, typesetting, and review of the resulting proof before it is published in its final form. Please note that during the production process errors may be discovered which could affect the content, and all legal disclaimers that apply to the journal pertain. 


\section{Diagnosing occult tumour cells and their predictive value in sentinel nodes of histologically negative patients with colorectal cancer.}

E.S. van der Zaag ${ }^{1}$, N. Kooij ${ }^{2}$, M.J. van de Vijver ${ }^{3}$, W.A. Bemelman ${ }^{4}$, H.M. Peters ${ }^{2}$, C.J.

$$
\text { Buskens }{ }^{1} \text {. }
$$

Departments of Surgery ${ }^{1}$ and Pathology ${ }^{2}$, Gelre Ziekenhuizen, Apeldoorn, The Netherlands.

Departments of Pathology ${ }^{3}$ and Surgery ${ }^{4}$, Academic Medical Center, Amsterdam, The Netherlands

Running title: Sentinel node procedure for occult tumour cells

Word count: 2809

\section{Corresponding address:}

E.S. van der Zaag

Department of Surgery

Gelre Ziekenhuizen

Albert Schweitzerlaan 31

7334 DZ Apeldoorn

The Netherlands

0031-55-8446016

e.vanderzaag@gelre.nl 


\section{ABSRACT}

Purpose: Most studies on the sentinel node (SN) procedure in patients with colorectal cancer include immunohistochemical analysis of the SN only. To evaluate the real diagnostic accuracy of the SN-procedure with immunohistochemical analysis, the presence of occult tumour cells in all histologically negative lymph nodes was compared to the presence of these cells in SNs. Also the reproducibility of diagnosing occult tumour cells (OTC) and the sensitivity of three different antibodies was assessed.

Methods: Between November 2006 en July 2007, an ex vivo SN procedure was performed in 58 histologically N0 patients with colorectal cancer. All lymph nodes (n=908, mean 15.7) were step-sectioned and immunohistochemistry was performed using two antibodies against cytokeratins (Cam5.2, and CK 20) and one antibody against BerEp-4.

Results: OTC were identified in 19 of 58 patients, with micrometastases $(0.2-2 \mathrm{~mm})$ in 7 and isolated tumour cells $($ ITC $)(<0.2 \mathrm{~mm})$ in 12 patients. The overall agreement in diagnosing OTC between two independent pathologists was 86\%. A SN was identified in 53 of 58 patients. All micrometastases were found in SNs. In two patients with negative SNs, ITC’s were demonstrated in non-SNs (sensitivity 88\%, and overall accuracy 96\%).

Conclusion: Additional immunohistochemical analysis of histologically negative lymph nodes demonstrates occult tumour cells in 33\% of the patients resulting in an upstaging rate of $12 \%$. Occult tumour cells are predominantly found in the SN, therefore SN mapping has the potential to refine the staging system for patients with colorectal cancer.

Key words: Occult tumour cells, Sentinel lymph node, colorectal cancer 


\section{INTRODUCTION}

Sentinel lymph node (SN) mapping is an increasingly popular technique to improve staging accuracy for patients with colorectal cancer by identifying nodes with the highest likelihood to harbour metastatic disease. This technique has shown promising results for colon carcinomas with SN mapping accurately predicting nodal status in 80-100\%.[1-24] An advantage of SN mapping is the potential to use this technique for a more accurate and costeffective pathologic assessment of lymph node status. The additional stepwise sectioning combined with immunohistochemical analysis of the SN has been demonstrated to detect occult tumour cells (OTC) in up to 40\% of histologically negative patients with colorectal cancer[1-24], possibly identifying a patient group that may benefit from adjuvant systemic therapy.

However, previously reported results are difficult to interpret because most studies publishing SN results include immunohistochemical analysis of the SN only. This might result in flattering negative predicting values and sensitivity rates. Moreover, most studies published so far have not subdivided the finding of OTC into micrometastases and isolated tumour cells (ITC) on the basis of their dimensions as recommended by the American Joint Committee on Cancer (AJCC) staging manual.[25] This possibly results in an overestimation of the number of upstaged patients and makes the clinical significance of the detected OTC difficult to evaluate. The widespread use of SN immunohistochemical analysis in patients with breast cancer has demonstrated that stage migration due to SN mapping harbours the danger of potential misleading effects and artefacts in prognostication.[26] This highlights the need to differentiate correctly between clinically relevant (micro)metastases $(0.2-2 \mathrm{~mm})(\mathrm{pN} 1 \mathrm{mi}+)$ and immunohistochemically detected isolated tumour cells without prognostic significance $(<0.2 \mathrm{~mm})\left(\mathrm{pNOitc}^{+}\right)$ 
This is particularly so since the main purpose of SN mapping in patients with colorectal cancer is to establish a more accurate staging of patients at risk of recurrence due to lymfogenic spread and who could benefit from adjuvant chemotherapy.

For clinical application with therapeutical consequences, an immunohistochemical marker for OTC has to be both highly sensitive (i.e. detect the majority of tumour cells), and specific (i.e. absence of false positive staining of cells). Since most studies use different antibodies without a gold standard and uniform definition of OTC, the antibody of first choice for the detection of clinically relevant micrometastases in patients with colorectal cancer is still difficult to determine on the basis of published data.

We performed this study to evaluate the real diagnostic accuracy of upstaging N0 patients with colorectal cancer by SN-procedure with immunohistochemical analysis. Therefore the incidence of OTC in SNs was compared to the presence of these cells in all histologically negative lymph nodes of these patients. Two experienced pathologists independently assessed the presence of lymph node metastases. The detection of OTC was analysed by three different antibodies to determine the sensitivity and specificity of these antibodies. In addition, the presence of OTC was correlated to clinicopathological parameters. 


\section{PATIENTS AND METHODS}

\section{Patients}

Between November 2006 and July 2007, an ex vivo SN procedure was performed in 100 patients with colorectal carcinoma who were operated on with curative intent. Exclusion criteria for SN mapping were invasion of other organs (T4 carcinomas), or two simultaneous colorectal carcinomas. Patients with locally advanced rectal cancer who underwent neoadjuvant chemoradiotherapy were excluded because of stage migration before surgical treatment. Of the 100 patients 42 patients were shown to have macrometastases in one or more lymph nodes. The remaining 58 patients were histologically staged as N0 (Dukes A or B), and they comprise the population of the current study. All patients with colon cancer underwent an oncological resection, including the mesocolon of the vascular trunk. Patients with rectal carcinoma underwent total mesorectal excision (TME) after preoperative shortcourse radiotherapy comprising five fractions of five Gray. In addition, the mesenteric lymph nodes of 6 patients were included who underwent colonic resection for benign disease (e.g. Crohn's disease or diverticulosis) as a negative control group.

The study was done in accordance with the guidelines of the local ethics committee.

\section{Sentinel lymph node mapping}

In this study, the ex vivo lymph mapping was used since only this technique can also be performed easily in patients with rectal carcinomas. The ex vivo technique has been demonstrated to be as accurate as the in vivo technique in identifying $\mathrm{SNs}[27,28]$, and it facilitates standardised, uniform specimen processing and assessment, recognising that the principal limitation of this technique is its inability to detect a small percentage (1-10\%) of cases with aberrant lymphatic drainage.[2, 16, 19] After standard resection, 0.5-2 ml (depending on the volume of the tumour) patent blue V (Guerbet, Gorinchem, The 
Netherlands) was injected around the tumour with the colonic specimen left intact.[29] For colonic carcinomas, the mesocolon was inspected and the first one to four blue lymph nodes were identified as SNs and either dissected or marked with a suture. For rectal carcinomas the specimen was sent to the department of pathology immediately after resection in fresh state. The identification of blue nodes was performed at the department of pathology immediatly, to keep the circumferential resection margin intact.

\section{Immunohistochemical staining}

The surgical resection specimens were analysed at the pathology department using a standardised protocol. All lymph nodes (SNs and non-SNs) were collected in separate boxes and marked according to location, then cut in two with both sides stained with hematoxylin and eosin and evaluated for tumour involvement. Of the 58 histologically N0 patients, serial sectioning was performed at $500 \mu \mathrm{m}$ intervals of all lymph nodes from formalin-fixed and paraffin-embedded archival tissue blocks. Three serial sections at three separate levels were immunohistochemically stained with three different monoclonal antibodies: the anti-epithelial cell antibody Ber-EP4 (DAKO, The Netherlands), was combined with two anti-cytokeratin antibodies: the anti-CK20 antibody, with its expression limited to gastrointestinal epithelial cells (Euro Diagnostica, Arnhem, The Netherlands), and the anticytokeratin marker Cam5.2 directed against cytokeratin 7 and 8 expressed in all epithelial cells (Becton and Dickinson, Alphen aan den Rijn, The Netherlands). Appropriate positive and negative controls were added on each automated run, to confirm the sensitivity and specificity of the antibodies (sections of colonic carcinoma tissue served as positive controls; negative controls were obtained by omitting the primary antibody). The staining procedures have been described in detail previously.[29] 


\section{Microscopic evaluation and definitions}

All slides were reviewed by two independent experienced pathologists who were unaware of the clinical data. The type of involvement (single tumour cells or clusters), topography (lymph-angio invasion and/or lymph sinuses and/ or parenchyma) and extension of the lesion was assessed in each case (Figure 1).

Occult tumour cells were classified as either an ITC (diameter $<0.2 \mathrm{~mm}$ ) or a micrometastasis (diameter between $0.2 \mathrm{~mm}$ and $2 \mathrm{~mm}$ ). Patients were then restaged according to the AJCC classification.[25] OTC comprised of micrometastases $(0.2-2 \mathrm{~mm})(\mathrm{pN} 1 \mathrm{mi}+)$ and ITC $(<0.2 \mathrm{~mm})\left(\mathrm{pN} 0 \mathrm{itc}^{+}\right)$. In case of disagreement, the slides were re-evaluated in a consensus meeting. False-positive non-neoplastic haematopoeitic cells (e.g. reticular cells and plasma cells which can also show staining for cytokeratins), were discriminated from ITCs on the basis of histopathologic features.

\section{Statistical analyses}

The following definitions were used for calculations (Figure 2). Identification rate is the number of patients with one or more SN identified (b) divided by the total number of procedures (a) x 100\%. Sensitivity is the number of patients with an immunohistochemically positive SN (c) divided by the total number of patients with detected OTC (c+e) x 100\%. Negative SNs were considered false negative if one of the other regional lymph nodes (nonSNs) demonstrated micrometastases or ITCs (e). The accuracy of the immunohistochemical SN analysis suggests a conformity of the SN status and the regional nodal status, i.e. the total number of patients with an immunohistochemically positive SN (c) plus the number of patients with a true-negative SN (f)/ the number of patients with an identified SN (b) x 100\%. 
All statistical analyses were performed using the Statistical Software Package version 14.0 (SPSS INC., Chicago, IL, USA). Associations between clinicopathological features and the presence of micrometastases were analysed using Student's t-test (continuous variables) or Chi-squared test (categorical variables). P-values of 0.05 or less were considered statistically significant. 


\section{RESULTS}

\section{Restaging patients by detection of occult tumour cells}

Three serial sections of all 908 lymph nodes from 58 patients with N0 carcinomas were examined with three different antibodies (mean 15.7 lymph nodes per patient, range 6-42). In 27 patients none of the lymph nodes had metastases after immunohistochemical staining and in 8 patients one or more lymph nodes demonstrated false positive staining unanimously recognised by both pathologists. There was consensus on 6 patients with micrometastases and 9 patients with ITCs; overall agreement $86 \%$ (50 of 58 patients). For the remaining 8 patients there was discrepancy in the diagnosis by the two pathologists. In these 8 patients, one pathologist diagnosed one micrometastasis and 10 ITCs in 11 lymph nodes, whereas the other pathologist classified 2 lesions as micrometastases, 6 lesions as ITC and 3 lesions as false positive staining. It was noted that the discrepancy between micrometastases and ITCs was mainly due to differences in measuring multiple foci. According to the AJCC $6^{\text {th }}$ edition of TNM classification of malignant tumours, clusters of tumour cells are considered as one focus if the nests are separated by a few cells, and when in doubt the lower category should be selected to prevent upstaging. In a consensus meeting the following was agreed upon: 52 lymph nodes with OTC were found in 19 of the 58 patients (33\%); seven patients had micrometastases $(12 \% \mathrm{pN} 1 \mathrm{mi}+)$ and 12 patients had ITCs (21\% pN0itc+)(Table 1$)$.

The presence of OTC (micrometastases and ITCs combined) was not related to any clinicopathological characteristic (Table 2). Although micrometastases and ITCs were found more frequently in tumours infiltrating the serosa and in tumours larger than $5 \mathrm{~cm}$, this was not statistically significant. Since micrometastases are thought to represent a different level of clinical significance, a correlation between $\mathrm{pN} 1(\mathrm{mi}+)$ versus pN0 (itc+/-) and clinicopathological characteristics was also analysed. The presence of micrometastases was 
also not related to tumour infiltration depth, differentiation grade, and extent of tumour spread, but a significant relation with lymphangio-invasion could be demonstrated $(\mathrm{p}<0.001)$.

\section{Sensitivity and specificity of three different antibodies}

No epithelial cells with atypical nuclear features characteristic of carcinoma cells were identified in lymph nodes from six control patients operated upon for benign disease, although occasional staining for keratin was observed in stellate cells located in the interfollicular regions of the nodes consistent with staining of reticulum cells. However, this pattern was easily distinguishable from the staining of carcinoma cells.

Each micrometastasis was detected with all three antibodies, as were 39 of 45 ITC-positive lymph nodes. All ITCs were detected with BerEP4. Six OTC were not detected with CK20 and two were missed with Cam5.2. It was noted that the intensity of staining with Cam5.2 and CK20 was related to differentiation of the primary tumour, and the undetected ITCs were found in lymph nodes of patients with a dedifferentiated tumour.

In $18 \%$ of the patients false-positive staining was detected with BerEP4 (e.g. reticulocytes, fibroblasts and mastcells) and this antibody yielded the most discordant classifications of ITCs and false-positive stained cells between the two pathologists. False-positive staining was less frequently encountered with Cam5.2 (although there was occasional staining of dendritic cells) and was hardly seen with CK20 immunohistochemical staining. These results would make Cam5.2 the antibody of first choice since it demonstrated the most consistent staining with high sensitivity and acceptable specificity.

\section{Diagnostic value of SN mapping}

The SN (median two SNs, range 1-4) was found in 53 of the 58 N0 patients (identification rate $91 \%$ ). Of the five patients in which the SN could not be identified, two patients demonstrated OTC in lymph nodes; these cells were all ITC. The remaining 53 patients were 
evaluated for the calculation of the diagnostic value of the SN. Overall, OTC were found in 17 patients; of which 15 were found in the SN and two in a non SN. Resulting in a sensitivity of $88 \%(15 / 17)$ and a negative predictive value of 94\% (34/36)(Figure 2). OTC were found in 18 of the 105 SNs (17\%), compared to 34 of 803 non-SNs (4\%); this difference was statistically significant $(\mathrm{p}<0.001)$. Because all seven micrometastases were found in the SNs exclusively, the accuracy of the SN procedure in upstaging patients is $100 \%$. 


\section{DISCUSSION}

\section{Value of SN procedure in refining staging of colorectal patients}

Our study emphasises the potential value of SN procedure for optimising staging of patients with colorectal cancer. The examination of 908 lymph nodes by stepwise sections and immunohistochemical analysis revealed OTC in 33\% of histologically N0 patients (12\% micrometastases and 21\% ITCs). OTC were predominantly found in SNs with an overall sensitivity of SN mapping for OTC of $88 \%$.

A large number of studies already addressed the value of SN mapping for colorectal carcinomas (Table 3).[1-24] In reviewing the literature, most studies demonstrate identification rates and accuracy rates varying from 80 to $100 \%$, and conclude that this technique can predict lymph node status with good accuracy rates. However, in these studies the percentage of histologically N0 patients is often more than $50 \%$ which makes the presented accuracy rates difficult to interpret.[1-7, 9-17, 19-23] This is merely because accuracy rates up to $90 \%$ may be accompanied by sensitivity rates and false negative rates of 50\%.[3, 7, 16, 19-21]

For clinical use the SN procedure should be both highly sensitive and specific. Evaluating upstaging percentages in studies lacking immunohistochemically analysis of non-SNs harbours the danger of an underestimation of sensitivity rates and the presentation of flattering negative predictive values. The primary role of SN procedure in patients with colorectal cancer is to increase the accuracy of staging N0 patients by identifying and analysing those nodes with the highest likelihood to harbour metastatic disease in a cost-effective manner. Therefore, it is of great importance that OTC are predominantly found in SNs. We demonstrate that the incidence of OTC is more than four times higher in SNs compared to non-SNs. Our results are in agreement with two previous studies that showed SNs to have the highest probability of harbouring OTC.[23, 24] 


\section{Classification and detection of occult tumour cells}

However, our study also emphasises that the classification of OTC remains difficult. Reliable and reproducible discrimination between micrometastases (pN1) and ITCs (pN0) is an essential component of adjuvant treatment planning. In analysing discrepant diagnoses for clinically relevant micrometastases between the two pathologists, we observed that the most challenging issue was whether multiple tumour clusters should be measured as one. A useful guideline in the AJCC system is that when controversy exists, the lower category should be selected. This recommendation was used during the consensus meeting. Another problem was the distinction between ITCs and false positively staining (non-tumour) cells. Although this has no impact on treatment recommendations, the inter-observer variation highlights the need for well defined antibodies.[31] Our data suggest that Cam5.2 would be the antibody of first choice for the detection of OTC. The anticytokeratin-marker BerEP-4 is more sensitive but has an almost 20\% false positive rate with high inter-observer variation. The use of the highly specific anti-CK20 with its expression limited to gastrointestinal epithelial cells can not be recommended due to its loss of expression in dedifferentiated tumours, resulting in low specificity.

\section{True upstaging rate of $\mathrm{SN}$ mapping and predictive value}

Comparing the incidence of clinically relevant upstaging by SN mapping with immunohistochemical analysis to literature is difficult. Before the revised TNM classification was introduced in 2003 micrometastases were not distinguished from ITCs.[31] Only three studies discriminated micrometastatic disease from ITCs,[3, 7, 19] with low incidence of micrometastatic disease varying from 5 to $10 \%$. Other studies reporting higher upstaging rates all included ITCs in their findings.[5, 10, 12, 13, 23, 24] This variation in definition of micrometastases makes it difficult to reach well-founded conclusions on the role of OTC and 
could explain the controversial prognostic significance of OTC. So far, only two studies have analysed the prognostic significance of micrometastatic disease in SNs with a decreased disease-specific survival in the pN1(mi+) group.[10,11] All other studies commenting on prognostic significance of OTC did not perform SN mapping.[33] Most studies failed to demonstrate a relation between the presence of OTC and tumour recurrence or survival. Messerini et al. demonstrated that the inclusion of ITCs should probably be regarded as a confounding factor in these studies.[33] Although our study was not designed to comment on the prognostic significance of OTC, the relation between lymphangio-invasion of tumour cells and micrometastases is suggestive of clinical relevance. Especially since this relation could not be demonstrated between lymphangio-invasion and ITCs.

\section{Conclusion}

Occult tumour cells are predominantly found in the SN with a true upstaging rate of $12 \%$ in patients with pN0 colorectal cancer. For immunohistochemical staining Cam5.2 seems the antibody of choice with an overall agreement of pathologist of $88 \%$ in staging patients. The SN procedure has the potential to refine the staging system for patients with colorectal cancer. Further survival analyses should be awaited to reveal the real prognostic relevance of these findings. 


\section{Acknowledgements}

The authors greatly acknowledge J. van Benthem and dr E. Weltevreden from the Gelre Hospital Department of Pathology for excellent technical assistance in staining and reviewing all immunohistochemically stained slides. Dr. W. Bouma is greatly acknowledged for supporting this study and critically reading the manuscript.

\section{Conflict of interest statement:}

All authors disclose any financial and personal relationships with other people or organisations that could inappropriately influence our work.

\section{Role of the funding source:}

All authors state there is no role of funding sources. 


\section{REFERENCES}

1. Matter M, Winckler M, Aellen S, Bouzourene H. Detection of metastatic disease with sentinel lymph node dissection in colorectal carcinoma patients. Eur J Surg Oncol 2007; 33:1183-90.

2. Kelder W, Braat AE, Karrenbeld A, Grond JA, De Vries JE, Oosterhuis JW, Baas PC, Plukker JT. The sentinel node procedure in colon carcinoma: a multi-centre study in The Netherlands. Int J Colorectal Dis 2007; 22:1509-14.

3. Bembenek AE, Rosenberg R, Wagler E, Gretschel S, Sendler A, Siewert JR, Nährig J, et al. Sentinel lymph node biopsy in colon cancer: a prospective multicenter trial. Ann Surg 2007; 245:858-63.

4. Stojadinovic A, Nissan A, Protic M, Adair CF, Prus D, Usaj S, Howard RS, Radovanovic D, et al. Prospective randomized study comparing sentinel lymph node evaluation with standard pathologic evaluation for the staging of colon carcinoma: results from the United States Military Cancer Institute Clinical Trials Group Study G1-01. Ann Surg 2007; 245:864-6.

5. Van Schaik PM, Van der Linden JC, Ernst MF, Gelderman WA, Bosscha K. Ex vivo sentinel lymph node “mapping” in colorectal cancer. Eur J Surg Oncol 2007; $33: 1177-82$.

6. Bianchi PP, Ceriani C, Rottoli M, Torzilli G, Roncalli M, Spinelli A, Montorsi M. Laparoscopic lymphatic mapping and sentinel lymph node detection in colon cancer: technical aspects and preliminary results. Surg Endosc 2007; 21:1567-71.

7. Thomas KA, Lechner J, Shen P, Waters GS, Geisinger KR, Levine EA. Use of sentinel node mapping for cancer of the colon: ‘to map or not to map’. Am Surg 2006; 72:606-11. 
8. Smith J, Hwang H, Wiseman KW, Filipenko D, Phang PT. Ex vivo sentinel lymph node mapping in colon cancer: improving the accuracy of pathologic staging? Am J Surg 2006; 191:665-8.

9. Saha S, Seghal R, Patel M, Doan K, Dan A, Bilchik A, Beutler T, Wiese D, Bassily N, Yee C. A multicenter trial of sentinel lymph node mapping in colorectal cancer: prognostic implications for nodal staging and recurrence. Am J Surg 2006; 191:30510.

10. Codignola C, Zorzi F, Zaniboni A, Mutti S, Rizzi A, Padolecchia E, Morandi GB. Is there any role for sentinel node mapping in colorectal cancer staging? Personal experience and review of the literature. Jpn J Clin Oncol 2005; 35:645-50.

11. Braat AE, Oosterhuis JW, Moll FC, de Vries JE, Wiggers T. Sentinel node detection after preoperative short-course radiotherapy in rectal carcinoma is not reliable. Br J Surg 2005; 92:1533-8.

12. Cox ED, Kellicut D, Adair C, Marley K, Otchy DP, Peoples GE. Sentinel lymph node evaluation is technically feasible and may improve staging in colorectal cancer. Curr Surg 2002; 59:301-6.

13. Smith FM, Coffey JC, Khasri NM, Walsh MF, Parfrey N, Gaffeny E, Stephens R, Kennedy MJ, Kirwan W, Redmond HP. Sentinel nodes are identifiable in formalinfixed specimens after surgeon-performed ex vivo sentinel lymph node mapping in colorectal cancer. Ann Surg Oncol 2005; 12:504-9.

14. Bell SW, Mourra N, Flejou JF, Parc R, Tiret E. Ex vivo sentinel lymph node mapping in colorectal cancer. Dis Colon Rectum 2005 ; 48 :74-9.

15. Paramo JC, Summerall J, Poppiti R, Mesko TW. Validation of sentinel node mapping in patients with colon cancer. Ann Surg Oncol 2002; 9:529-31. 
16. Fitzgerald TL, Khalifa MA, Al Zahrani M, Law CH, Smith AJ. Ex vivo sentinel lymph node biopsy in colorectal cancer: a feasibility study. J Surg Oncol 2002; 80:2732.

17. Bendavid Y, Latulippe JF, Younan RJ, Leclerc YE, Dube S, Heyen F, Morin M, Girard R, et al. Phase I study on sentinel lymph node mapping in colon cancer: a preliminary report. J Surg Oncol 2002; 7981-4.

18. Joosten JJ, Strobbe LJ, Wauters CA, Pruszczynski M, Wobbes T, Ruers TJ. Intraoperative lymphatic mapping and the sentinel node concept in colorectal carcinoma. Br J Surg 1999; 86:482-6.

19. Bilchik AJ, Hoon DS, Saha S, Turner RR, Wiese D, DiNome M, Koyanagi K, et al. Prognostic impact of micrometastases in colon cancer: interim results of a prospective multicenter trial. Ann Surg 2007; 246:568-75.

20. Bertagnolli M, Miedema B, Redston M, et al. Sentinel node staging of resectable colon cancer: results of a multicenter study. Ann Surg 2004; 240:624-8.

21. Faerden AE, Sjo OH, Andersen SN, Hauglann B, Nazir N, Gravdehaug B, Moberg I, Svinland A, Nesbakken A, Bakka A. Sentinel node mapping does not improve staging of lymph node metastasis in colonic cancer. Dis Colon Rectum 2008; 51:891-6.

22. Yagci G, Unlu A, Kurt B, Can MF, Kaymakcioglu N, Cetiner S, Tufan T, Sen D. Detection of micrometastases and skip metastases with ex vivo sentinel node mapping in carcinoma of the colon and rectum. Int J Colorectal Dis 2007; 22:167-73.

23. Bembenek A, Schneider U, Gretschel S, Fischer J, Schlag PM. Detection of lymph node micrometastases and isolated tumor cells I sentinel and nonsentinel lymph nodes of colon cancer patients. World J Surg 2005; 29:1172-5. 
24. Turner RR, Nora DT, Trocha SD, Bilchik AJ. Frequency and nature of cytokeratinpositive cells in sentinel and nonsentinel lymph nodes. Arch Pathol Lab Med 2003; 127:673-9.

25. Green FL, Page DL, Fleming ID, et al. AJCC cancer staging manual. $6^{\text {th }}$ ed. New York, Springer 2002.

26. Singletary SE, Allred C, Ashley P, et al. Revision of the American Joint Committee on Cancer staging system for breast cancer. J Clin Oncol 2002; 20: 3628-36.

27. Teuch JJ, Pessaux P, Fiore FD, et al. Sentinel node mapping in coloncarcinoma : invivo versus ex-vivo approach. Eur J Surg Oncol 2006 ; 32 :158-161.

28. Wood TF, Saha S, Morton DL, et al. Validation of lymphatic mapping in colorectal cancer: in vivo, ex vivo, and laparoscopic techniques. Ann Surg Oncol 2001; 8:150157.

29. van der Zaag ES, Buskens CJ, Kooij N, Akol H, Peters HM, Bouma WH, Bemelman WA. Improving staging accuracy in colon and rectal cancer by sentinel lymph node mapping: a comparative study. Eur J Surg Oncol 2009; Mar 3.

30. Borgen E, Beiske K, Trachsel S, Nesland JM, Kvalheim G, Herstad TK, et al. Immunocytochemical detection of isolated epithelial cells in bone marrow: nonspecific staining and contribution by plasma cells directly reactive to alkaline phosphatase. J Pathol 1998;185:427-434.

31. Redston M, Compton CC, Miedema BW, Niedzwiecki D, Dowell JM, Jewell SD, Fleshman JM, Bem J, Mayer RJ, Bertagnolli MM. Analysis of micrometastatic disease in sentinel lymph nodes from resectable colon cancer: results of cancer and leukaemia group B trial 80001. J Clin Oncol 2006; 24:878-883. 
32. De Haas RJ, Wicherts DA, Hobbelink MG, Borel Rinkes IH, Schipper ME, Van der Zee JA, Van Hillegersberg R. Sentinel lymph node mapping in colon cancer: current status. Ann Surg Oncol 2007; 14:1070-80.

33. Messerini L, Cianchi F, Cortesini C, Comin CE. Incidence and prognostic significance of occult tumor cells in lymph nodes from patients with stage IIA colorectal carcinoma. Hum Pathol 2006; 37:1259-67. 


\section{Table 1}

Classification of immunohistochemical staining results by two independent pathologists of 58 histologically negative patients with colorectal cancer.

\begin{tabular}{|c|c|c|c|c|c|}
\hline & \multirow[b]{2}{*}{ Micrometastasis } & \multicolumn{3}{|c|}{ Pathologist 1} \\
\hline & & & $\begin{array}{l}\text { Isolated tumour } \\
\text { cells }\end{array}$ & $\begin{array}{c}\text { False positive } \\
\text { staining }\end{array}$ & Absent \\
\hline \multirow{4}{*}{ Pathologist 2} & Micrometastasis & 6 & 1 & 0 & 0 \\
\hline & $\begin{array}{c}\text { Isolated tumour } \\
\text { cells }\end{array}$ & 1 & 9 & 4 & 0 \\
\hline & $\begin{array}{l}\text { False positive } \\
\text { staining }\end{array}$ & 0 & 5 & 8 & 3 \\
\hline & Absent & 0 & 0 & 2 & 27 \\
\hline \multicolumn{2}{|l|}{ Consensus } & 7 & 12 & 10 & 29 \\
\hline
\end{tabular}




\section{Table 2}

The presence of occult tumour cells correlated to tumour characteristics of 58 patients

\begin{tabular}{|c|c|c|c|c|c|}
\hline \multirow[b]{2}{*}{ Tumour characteristics } & \multirow[b]{2}{*}{$\mathrm{N}=58$} & \multicolumn{3}{|c|}{ Occult tumour cells } & \multirow[b]{2}{*}{ p-value } \\
\hline & & $\begin{array}{c}\text { Micrometastasis } \\
(\mathrm{N}=7)\end{array}$ & $\begin{array}{l}\text { ITCs } \\
(\mathrm{N}=12)\end{array}$ & $\begin{array}{l}\text { Absent } \\
(\mathrm{N}=39)\end{array}$ & \\
\hline \multirow[t]{3}{*}{ Depth of invasion ${ }^{\mathrm{a}}$} & $\mathrm{T} 1(4)$ & 0 & 0 & 4 & ns \\
\hline & T2 (18) & 2 & 3 & 13 & \\
\hline & T3 (36) & 5 & 9 & 22 & \\
\hline \multirow[t]{3}{*}{ Differentiation grade } & well (4) & 0 & 0 & 4 & ns \\
\hline & moderate (45) & 7 & 10 & 28 & \\
\hline & poor (9) & 0 & 2 & 7 & \\
\hline \multirow[t]{2}{*}{ Extend of tumour spread } & $<5 \mathrm{~cm}(34)$ & 2 & 6 & 26 & ns \\
\hline & $>5 \mathrm{~cm}(24)$ & 5 & 6 & 13 & \\
\hline \multirow[t]{2}{*}{ Lymphangio-invasion } & absent (51) & 3 & 12 & 36 & 0.001 \\
\hline & present (7) & 4 & 0 & 3 & \\
\hline
\end{tabular}

${ }^{a}$ T1: tumour limited to the (sub)mucosa, T2: tumour infiltrates muscularis propria, but not adventitia, T3: tumour infiltrates adventitia. 
Table 3

Predictive value of blue dye SN mapping in patients with colorectal cancer including immunohistochemical analyses (comparison of existing literature until may 2008; excluding duplicate series and princeps studies with updated publications).

\begin{tabular}{|c|c|c|c|c|c|c|c|c|c|c|}
\hline Study & $\mathrm{N}$ & $\begin{array}{l}\text { No LNs } \\
\text { (mean) }\end{array}$ & $\begin{array}{l}\text { N0 } \\
(\%)\end{array}$ & $\begin{array}{c}\text { Identification } \\
(\%)\end{array}$ & $\begin{array}{c}\text { Accuracy } \\
(\%)\end{array}$ & $\begin{array}{c}\text { False } \\
\text { neg } \\
(\%)\end{array}$ & $\begin{array}{c}\text { Sensitivity } \\
(\%)\end{array}$ & $\begin{array}{l}\text { Upstaging } \\
\text { (\%) }\end{array}$ & $\underset{\mathrm{a}}{\mathrm{ITC}}$ & Antibody \\
\hline \multicolumn{11}{|c|}{ Immunohistochemical analysis of SN only } \\
\hline Matter $^{1}$ & 52 & $30^{c}$ & 63 & 92 & - & $25^{\mathrm{d}}$ & $44^{\mathrm{d}}$ & 23 & $\mathrm{~N}$ & $\begin{array}{l}\text { CK11/CEA } \\
\text { /Ca19-9 }\end{array}$ \\
\hline \multirow{2}{*}{$\begin{array}{l}\text { Kelder }^{2} \\
\text { Bembenek }^{3}\end{array}$} & 69 & 11 & 73 & 97 & 96 & $30^{\mathrm{d}}$ & $89^{\mathrm{d}, \mathrm{f}}$ & 18 & $\mathrm{~N}$ & CK7/8/18 \\
\hline & 315 & 20 & 69 & 85 & 86 & 46 & 54 & $5 / 16^{\mathrm{g}}$ & $\mathrm{Y}$ & MNF16 \\
\hline Stojadinovic $^{4}$ & 162 & 18 & 65 & 98 & $90^{\mathrm{d}}$ & $31^{\mathrm{d}}$ & $69^{\mathrm{d}, \mathrm{f}}$ & 11 & $\mathrm{~N}$ & $\begin{array}{c}\text { AE1/AE3 } \\
\text { Cam5.2 }\end{array}$ \\
\hline Van Schaik ${ }^{5}$ & 44 & 10.5 & 52 & 94 & 100 & 0 & 100 & 30 & $\mathrm{~N}$ & LU-5 \\
\hline Bianchi $^{6}$ & 22 & $22^{\mathrm{C}}$ & 73 & 100 & 95 & 17 & 83 & 13 & $\mathrm{~N}$ & CK? \\
\hline Thomas $^{7}$ & 69 & 16 & 62 & 93 & 78 & 54 & $46^{\mathrm{f}}$ & $5 /-, \mathrm{e}$ & $\mathrm{Y}$ & CEA/CK \\
\hline Smith $^{8}$ & 17 & 16 & $41^{\mathrm{e}}$ & 94 & 100 & 0 & 100 & $20^{d}$ & $\mathrm{~N}$ & MNF116 \\
\hline Saha $^{9}$ & 500 & 15 & $50^{\mathrm{d}}$ & 98 & 96 & 10 & 90 & 26 & $\mathrm{~N}$ & AE1/AE3 \\
\hline Codignola $^{10}$ & 56 & 21 & 59 & 100 & $89^{\mathrm{e}, \mathrm{f}}$ & $11^{\mathrm{d}}$ & $86^{\mathrm{e}, \mathrm{f}}$ & $38^{d}$ & $\mathrm{~N}$ & Cam5.2 \\
\hline Braat $^{11}$ & 91 & $7.7^{\mathrm{e}}$ & $62^{e}$ & $90^{\mathrm{e}}$ & $90^{\mathrm{e}}$ & $26^{e}$ & $74^{\mathrm{e}, \mathrm{f}}$ & $12^{\mathrm{e}}$ & $\mathrm{N}$ & CK7/8 \\
\hline $\operatorname{Cox}^{12}$ & 17 & 18 & 82 & 100 & 100 & 0 & $100^{\mathrm{f}}$ & 29 & $\mathrm{~N}$ & AE1/AE3 \\
\hline Smith $^{13}$ & 40 & 17 & 56 & 98 & $95^{\mathrm{e}}$ & 12 & $88^{f}$ & $29^{d}$ & $\mathrm{~N}$ & Cam5.2 \\
\hline Bell $^{14}$ & $58^{\mathrm{b}}$ & 30 & 57 & 97 & $84^{e}$ & $16^{\mathrm{d}}$ & $64^{e}$ & 4 & $\mathrm{~N}$ & $\mathrm{CK}$ \\
\hline Paramo $^{15}$ & 55 & 12 & $67^{\mathrm{e}}$ & 82 & 98 & $3^{d}$ & $93^{e}$ & $11^{\mathrm{d}}$ & $\mathrm{N}$ & Cam5.2 \\
\hline Fitzgerald $^{16}$ & 26 & 15 & $87^{\mathrm{e}}$ & 88 & $91^{\mathrm{d}}$ & $9^{d}$ & $33^{\mathrm{e}}$ & 10 & $\mathrm{~N}$ & Cam5.2 \\
\hline Bendavid $^{17}$ & 20 & - & 55 & 90 & - & - & - & 25 & $\mathrm{~N}$ & AE1/AE3 \\
\hline Joosten $^{18}$ & 50 & $14^{\mathrm{c}}$ & 48 & 70 & $66^{\mathrm{e}}$ & 60 & 40 & 13 & $\mathrm{~N}$ & $\begin{array}{l}\text { LU-5/ } \\
\text { CK19 } \\
\end{array}$ \\
\hline Bilchik $^{19}$ & 141 & 17 & 73 & 99 & 91 & 39 & $61^{\mathrm{e}}$ & $8 / 22^{\mathrm{g}}$ & $\mathrm{Y}$ & CK \\
\hline Bertagnolli $^{20}$ & 72 & 17 & 66 & 92 & 80 & 54 & 46 & - & $\mathrm{N}$ & $\begin{array}{c}\text { AE1/AE3 } \\
\text { CEA }\end{array}$ \\
\hline \multicolumn{11}{|c|}{ Immunohistochemical analysis of all lymph nodes } \\
\hline \multirow{4}{*}{$\begin{array}{l}\text { Faerden }^{21} \\
\text { Yagci }^{22} \\
\text { Bembenek }^{23} \\
\text { Turner }^{24}\end{array}$} & 199 & $13^{\mathrm{c}}$ & 68 & 93 & 85 & 47 & 53 & 30 & $\mathrm{~N}$ & Cam5.2 \\
\hline & 47 & 19 & 57 & 98 & $91^{\mathrm{e}}$ & 20 & 80 & 15 & $\mathrm{~N}$ & $\begin{array}{c}\text { AE1/AE3/ } \\
\text { CEA }\end{array}$ \\
\hline & 55 & $26^{\mathrm{c}}$ & 70 & 85 & - & 4 & 96 & 39 & $\mathrm{~N}$ & MNF 116 \\
\hline & 51 & $14^{\mathrm{c}}$ & $55^{\mathrm{e}}$ & 100 & $88^{\mathrm{e}}$ & $26^{e}$ & $74^{\mathrm{e}}$ & 29 & $\mathrm{~N}$ & AE1/AE3 \\
\hline $\begin{array}{l}{ }^{\mathrm{C}} \mathrm{Dis} \\
{ }^{\mathrm{b}} \mathrm{Sp} \\
{ }^{\mathrm{c}} \mathrm{Me} \\
{ }^{\mathrm{d}} \mathrm{Dis} \\
{ }^{\mathrm{e}} \mathrm{Ca} \\
{ }^{\mathrm{f}} \mathrm{Ca} \\
{ }^{\mathrm{g}} \mathrm{Im}\end{array}$ & $\begin{array}{l}\text { rimin } \\
\text { imen } \\
\text { ian } \\
\text { repan } \\
\text { ulatec } \\
\text { unoh } \\
\text { icron }\end{array}$ & $\begin{array}{l}\text { cy betwe } \\
\text { value } \\
\text { stochem } \\
\text { etastase }\end{array}$ & stry r & $\begin{array}{l}\text { orted value } \\
\text { sults of SN } \\
\text { upstaging)/ }\end{array}$ & $\begin{array}{l}\text { Id calcula } \\
\text { cluded is } \\
\text { isolated }\end{array}$ & ensitiv & eport & ues al & & ed) \\
\hline
\end{tabular}




\section{Figure 1}

Representative examples of immunohistochemically detected occult tumour cells.

A: micrometastasis $>0.2 \mathrm{~mm}$. B: isolated tumour cell, cluster of cells $>0.2 \mathrm{~mm}$. C: isolated tumour cells, cluster of cells $<0.2 \mathrm{~mm}$ with characteristic nuclear features. D: false-positively staining cell

A

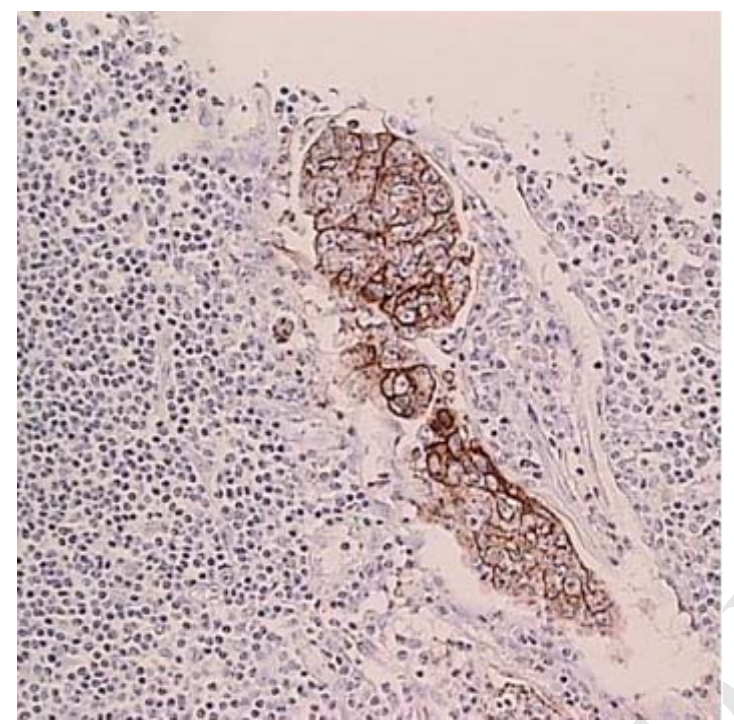

C

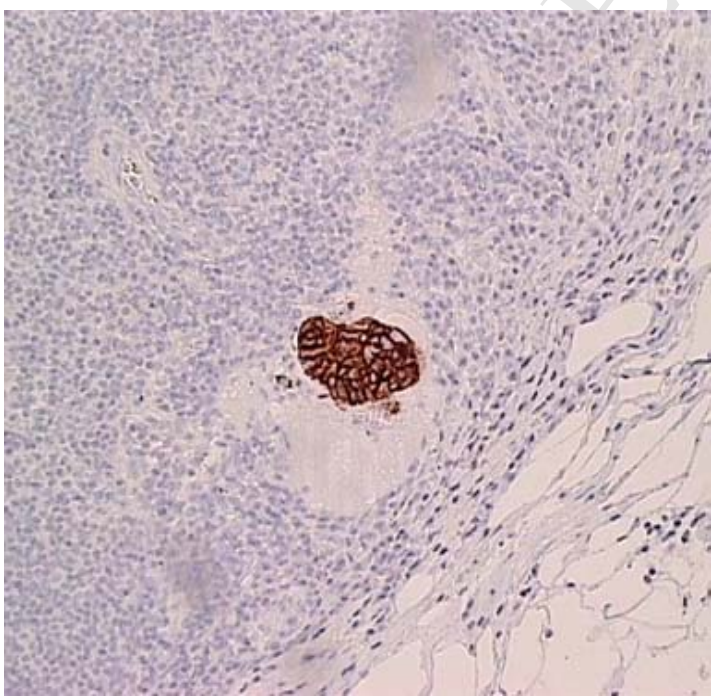

B

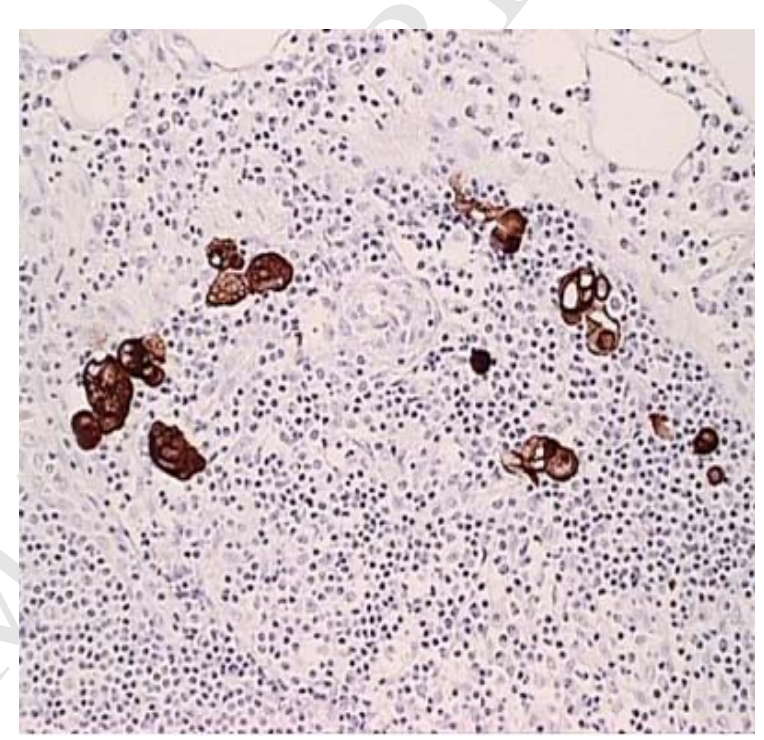

D

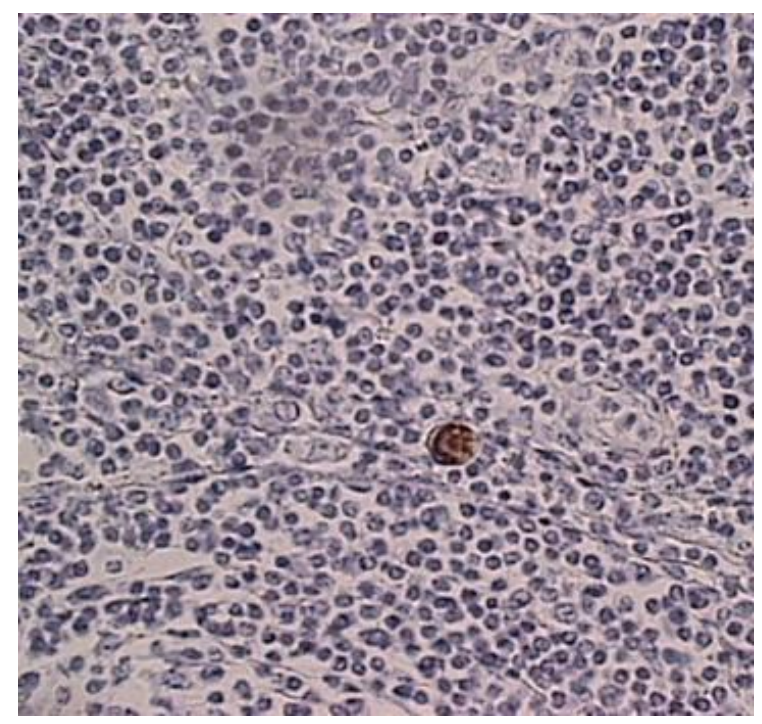




\section{Figure 2}

Flowchart. Predictive value of sentinel node mapping for occult tumour cells in histologically negative lymph nodes.

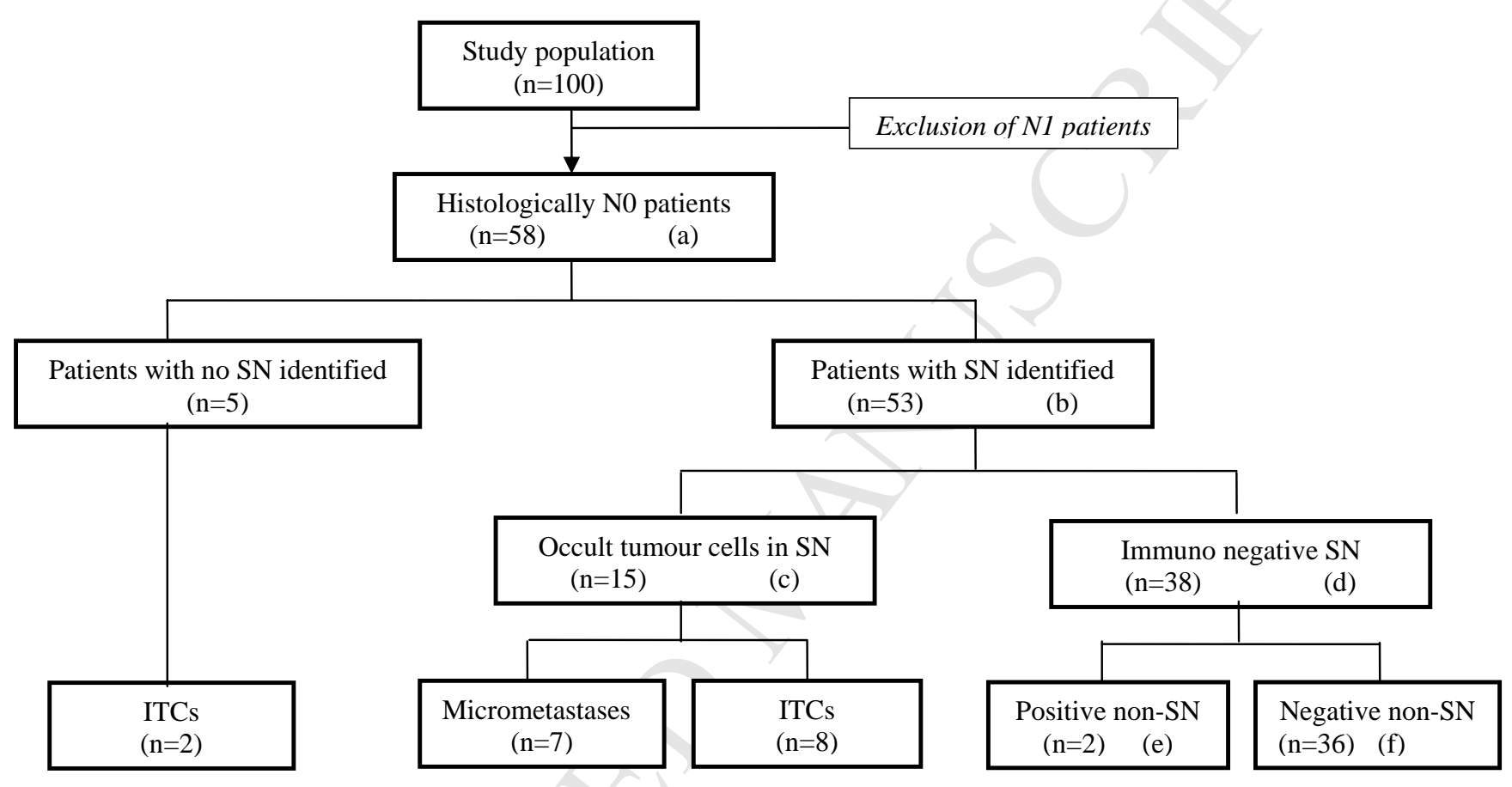

